\title{
Uncovering the roles of long non-coding RNAs in cancer stem cells
}

\author{
Xiaoxing Huang ${ }^{1 \dagger}$, Ruijing Xiao ${ }^{1 \dagger}$, Shan Pan ${ }^{1}$, Xiangyong Yang ${ }^{2}$, Wen Yuan', Zhenbo Tu', Ming Xu', Yufan Zhu', \\ Qian Yin ${ }^{1}$, Yingjie $\mathrm{Wu}^{1}$, Weidong $\mathrm{Hu}^{3}$, Liang Shao ${ }^{4}$, Jie Xiong ${ }^{1}$ and Qiuping Zhang ${ }^{1 *}$
}

\begin{abstract}
Cancer has been a major public health problem that has threatened human life worldwide throughout history. The main causes that contribute to the poor prognosis of cancer are metastasis and recurrence. Cancer stem cells are a group of tumor cells that possess self-renewal and differentiation ability, which is a vital cause of cancer metastasis and recurrence. Long non-coding RNAs refer to a class of RNAs that are longer than $200 \mathrm{nt}$ and have no potential to code proteins, some of which can be specifically expressed in different tissues and different tumors. Long noncoding RNAs have great biological significance in the occurrence and progression of cancers. However, how long non-coding RNAs interact with cancer stem cells and then affect cancer metastasis and recurrence is not yet clear. Therefore, this review aims to summarize recent studies that focus on how long non-coding RNAs impact tumor occurrence and progression by affecting cancer stem cell self-renewal and differentiation in liver cancer, prostate cancer, breast cancer, and glioma.
\end{abstract}

Keywords: Long non-coding RNAs, Cancer stem cells, Self-renewal, Malignant transformation, Tumor metastasis, Tumor recurrence

\section{Background}

According to the result of Human Genome Project, only approximately 20 thousand genes of human genome have the encoding protein ability [1]. At the same time, only $5-7 \%$ of human genes can be stably transcribed. The vast majority of RNAs are therefore unable to be translated into protein and are termed non-coding RNAs [2-4]. Non-coding RNAs used to be considered by scientists to be "junk RNAs"; however, an increasing body of evidence suggests that non-coding RNAs play an important role in both physiological and pathological conditions [5-7].

Long non-coding RNAs (LncRNAs) are a class of noncoding RNAs that have no potential to code proteins and are more than 200 nucleotides in length. Portions of LncRNAs can be specifically expressed in different tissues and different cancers [8-10]. According to the literature, the disorder of LncRNAs is closely related to

\footnotetext{
* Correspondence: qpzhang@whu.edu.cn

${ }^{\dagger}$ Equal contributors

'Department of Immunology, School of Basic Medical Science, Wuhan

University, Wuhan 430071, China

Full list of author information is available at the end of the article
}

the occurrence and development of various cancers, such as leukemia, breast cancer, gastric cancer, colon cancer, liver cancer, lung cancer, and cholangiocarcinoma [11-17]. The GENCODE consortium (version 18) has confirmed the existence of 13,562 LncRNAs, and approximately $2 / 3$ of them are located between genes, which are termed long intergenic ncRNAs (lincRNAs). Others include overlapping, antisense, and intronic LncRNAs [18]. Most LncRNAs are transcribed by RNA polymerase II to be spliced, polyadenylated, and 5' capped $[19,20]$. LncRNAs work mainly in four modes: signal, decoy, guide, and scaffold [21, 22]. They affect the transcription of genes and play a regulating role (Fig. 1) [22]. Signal: LncRNAs can signal the space, time, and expression of gene transcription to reflect the integrative biological outcome of transcription factors and signaling pathways controlling gene expression. Decoy: LncRNAs can bind and titrate away the protein or RNA target. Guide: LncRNAs can guide RNA-binding proteins to special target genes, either in the near or in the distant target genes. Scaffold: LncRNAs can assemble different proteins to form complexes to initiate the special biological functions [21, 22]. Compared with coding 


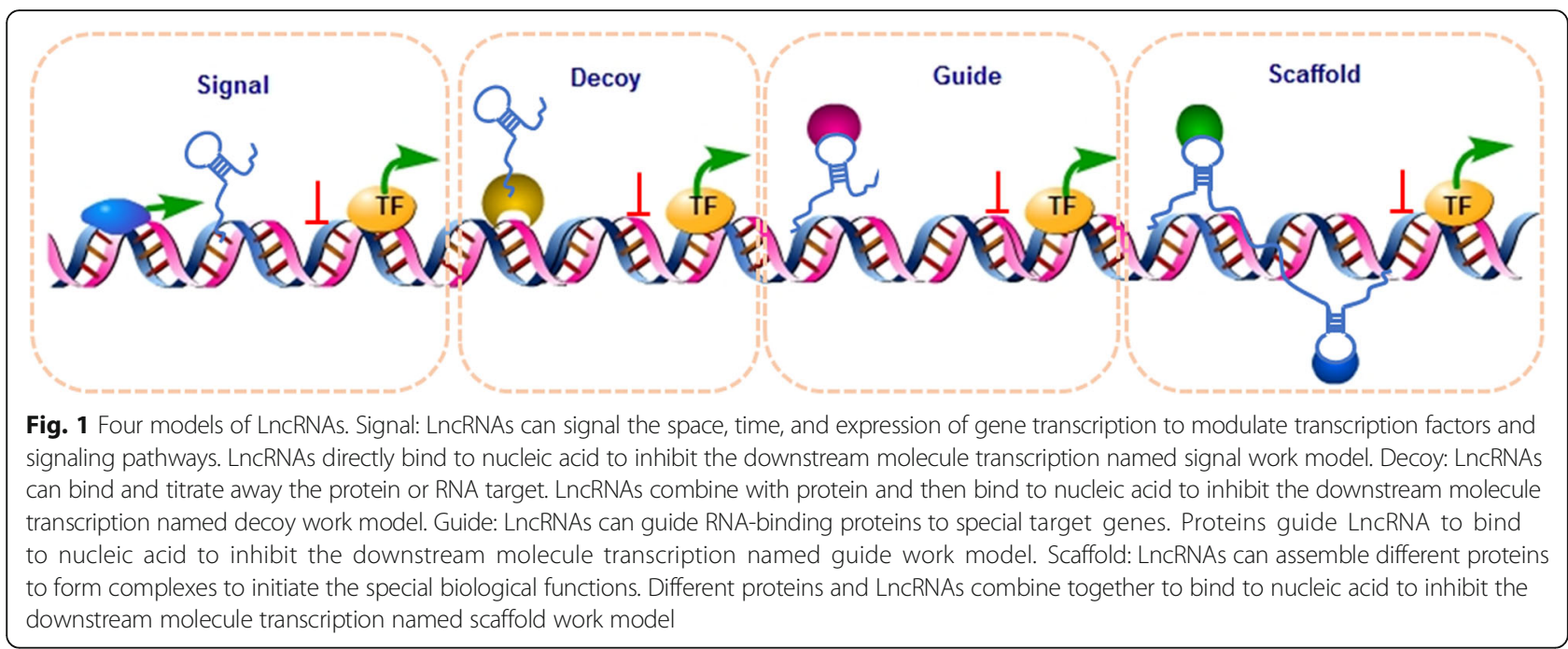

genes and other non-coding RNAs such as microRNAs (miRNAs), LncRNAs are highly conserved [23]. Their high conservation and versatility have made them important in cancer research in recent years.

The tumor complex contains heterogeneous cells of different differentiation degrees [24]. Cancer stem cells (CSCs) are a group of tumor cells that have differentiation and self-renewal ability [25]. In 2003, Visvader and Linderman first defined CSCs in acute myeloid leukemia [26]. Recently, more research has shown that CSCs are involved in the occurrence, development, invasion, metastasis, and drug resistance of numerous solid tumors [27-30], which is closely related to poor tumor prognosis. Removal of CSCs is considered a new hope for the eradication of malignant tumors and the prevention of tumor recurrence [31].

Some research has demonstrated that the aberrant expression of LncRNAs in malignant tumors is closely related to the function of CSCs. Numerous LncRNAs modulate the functions of CSCs by regulating OCT4, SOX2, KLF4, and other classic stem cell-related pathways [32-34]. In addition, other LncRNAs contribute to CSC functions and tumor occurrence and development by inhibiting the miR-200 family, let-7, miR-140, and other miRNAs [35-37]. In recent years, research regarding LncRNAs and CSCs gradually became important to cancer researchers. This review aims to summarize the current research status of LncRNA and CSCs in different tumors and to explore the significance of LncRNA in the removal of CSCs and tumor therapy.

\section{Hepatocellular carcinoma}

Hepatocellular carcinoma (HCC) is a global health problem and is ranked sixth worldwide for malignant tumors [38]. Over 700,000 patients are newly diagnosed with HCC every year [39]. Thus, the mechanisms of HCC development and progression and therapeutic targets and methods have been the focus of scientists. Increasingly, research suggests that LncRNAs participate in the self-renewal and proliferation of HCC stem cells by different mechanisms and play important roles in HCC deterioration.

According to previous research, the high trimethylation level of histone H3K4 and H3K27 was linked to low differentiation, a large volume of neoplastic foci, multiple tumors, vascular invasion, and poor prognosis of HCC $[40,41]$. Li et al. found that LncRNA CUDR could enhance the interaction between SET1A and phosphorylated RB1 (pRB1) in HCC, and the complex they formed resulted in a high level of $\mathrm{H} 3 \mathrm{~K} 4$ trimethylation, which participated in the malignant transformation of $\mathrm{HCC}$ stem cells via altering telomere length [42]. At the same time, other research suggests that LncRNA CUDR can also function as an oncogene by the CUDR-HULC/ CUDR- $\beta$-catenin signaling pathway [43]. Furthermore, CUDR inhibits the methylation of the gene promoter LncRNA H19 by combining with Cyclin-D to form the complex CUDR-CyclinD1, which upregulates the expression of LncRNA H19 and finally upregulates the expression of TERT and C-Myc to promote the self-renewal and proliferation of HCC stem cells [44] (Fig. 2 (Part 1)). Thus, it can be seen that LncRNA CUDR plays an important role in the self-renewal and proliferation of HCC stem cells by multiple signaling pathways.

In addition, $\mathrm{Li}$ et al. reported that LncRNA HOTAIR can inhibit the trimethylation level of its downstream histone H3K36 by suppressing the expression of SETD2, which can enhance the malignant proliferation of HCC stem cells and accelerate the progression of HCC by affecting the repair of aged histones, microsatellite stability, and cell cycle-related genes [45] (Fig. 2 (Part 2)). Thus, it can be seen that LncRNA can enhance the 


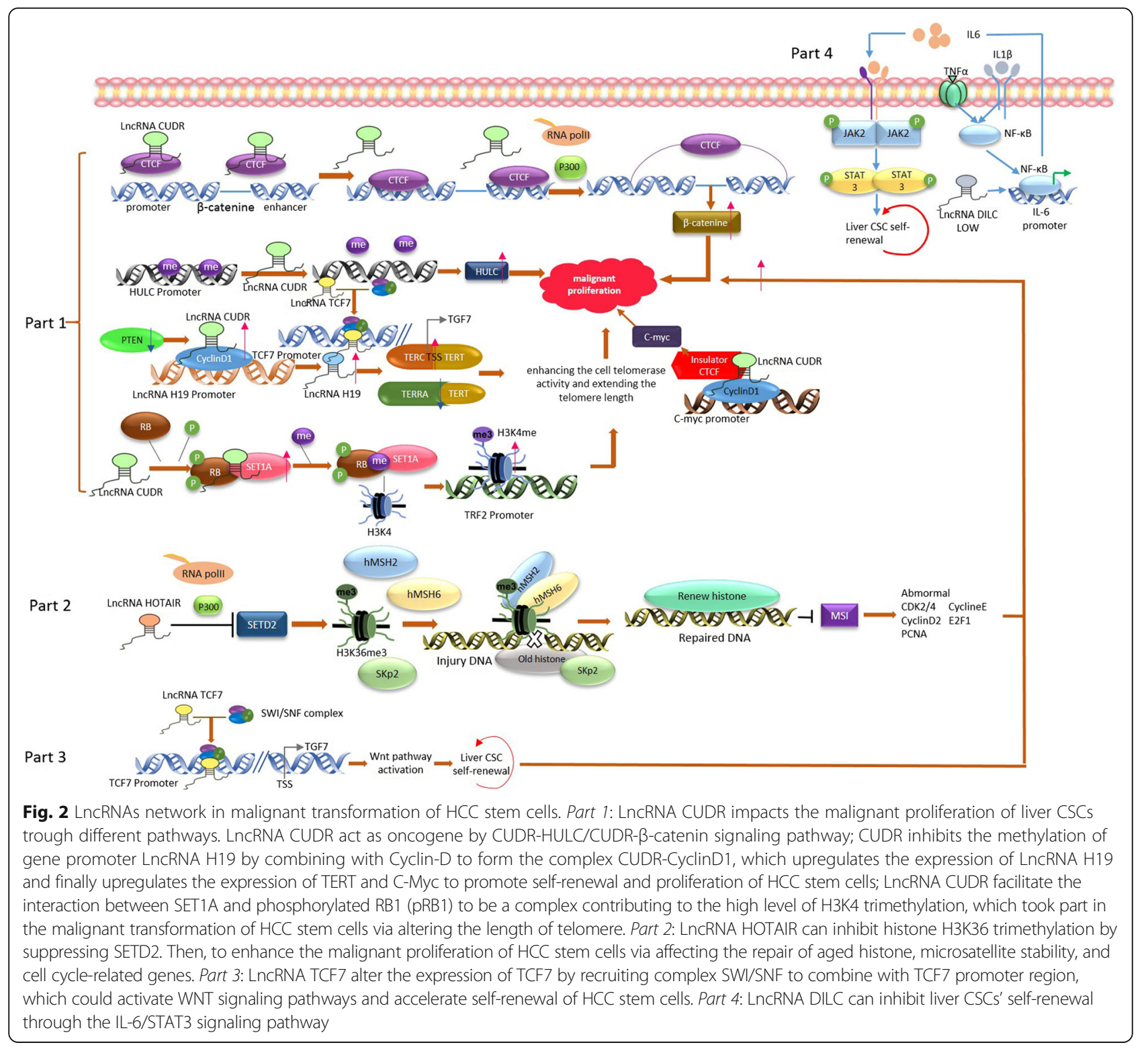

malignant transformation of HCC stem cells by regulating the abnormal modification of histones. At the same time, scientists have reported that LncRNAs can accelerate the development and progression of $\mathrm{HCC}$ by altering the classic signaling pathways that are related to HCC stem cells. For instance, lncTCF7 can alter the expression of TCF7 by recruiting SWI/SNF to combine with the TCF7 promoter region, which could activate the WNT signaling pathways and accelerate self-renewal of HCC stem cells and the deterioration of HCC [46] (Fig. 2 (Part 3)). LncRNA DILC can inhibit the self-renewal of HCC stem cells by blocking the HCC autocrine IL-6/ STAT3 signaling pathway [47] (Fig. 2 (Part 4)). Moreover, LncRNAs can also take part in regulating the self-renewal and proliferation of HCC stem cells via inhibiting the combination of microRNA and target genes, playing a role in secretion in the tumor microenvironment $[48,49]$. In conclusion, the results of several studies have indicated that LncRNAs play important roles in the malignant transformation of $\mathrm{HCC}$ stem cells, providing a new possibility for HCC clinical treatment.

\section{Prostate cancer}

Prostate cancer is the second most frequent cancer in the world [50]. Androgen receptor plays an important role in the occurrence and development of prostate cancer [51]. In the clinic, androgen blockade therapy is the standard treatment for prostate cancer, but androgen blocking resistance often appears after 1-2 years [52, 53]. Presently, research regarding the relationship between LncRNAs and prostate CSCs is still in the beginning stages. Scientists have found that LncRNA HOTAIR and 
LncRNA H19, which play important roles in liver CSCs self-renewal, can also affect the function of prostate CSCs. Lei Li and other researchers have found that after androgen blockade therapy in prostate cancer, a large number of mast cells can aggregate in the tumor microenvironment and then increase the number of stem cells and progenitor cells through the downstream androgen receptor signaling pathway. Mast cells enable the PCR2-LncRNA HOTAIR complex to bind to the $5^{\prime}$-flanking promoter region of the androgen receptor gene and thus suppress androgen receptor transcription, thereby affecting the expression of MMP9 and increasing $\mathrm{CD}_{133^{+}}$stem/progenitor cells to promote the invasion of prostate cancer [54] (Fig. 3). Forming complexes with extraneous molecules and then binding to the promoter of target gene to prevent its transcription is a common working model of LncRNAs. In prostate cancer, the inhibition of LncRNA H19 can repress the expression of classic stem cells related factors SOX2 and Oct4. At the same time, the inhibition of LncRNA H19 could repress the clone forming ability of prostate CSCs. This indicates that LncRNA H19 plays an important role in the maintenance of stemness in prostate CSCs [55]. Until now, studies regarding the functions of LncRNA on prostate CSCs are still limited, but it is believed that additional important LncRNAs will be found in prostate CSCs.

\section{Breast cancer}

Breast cancer has long been a serious threat to the health of women around the world [56]. With in-depth studies on the occurrence and development of breast cancer, researchers have found that breast CSCs appear resistant to chemotherapy, radiotherapy, and hypoxia. Furthermore, breast CSCs exhibit high tumorigenicity and invasiveness, which are crucial to the occurrence, development, metastasis, and recurrence of breast cancer. According to the reports, LncRNAs can affect the characteristics of breast CSCs through various pathways, and have a great effect on breast cancer progression. During the occurrence and progression of breast cancer, the epithelial mesenchymal transition (EMT) is closely related to the function of breast CSCs, and numerous LncRNAs can promote or inhibit the metastasis and invasion of breast cancer cells by inducing or inhibiting EMT [57].

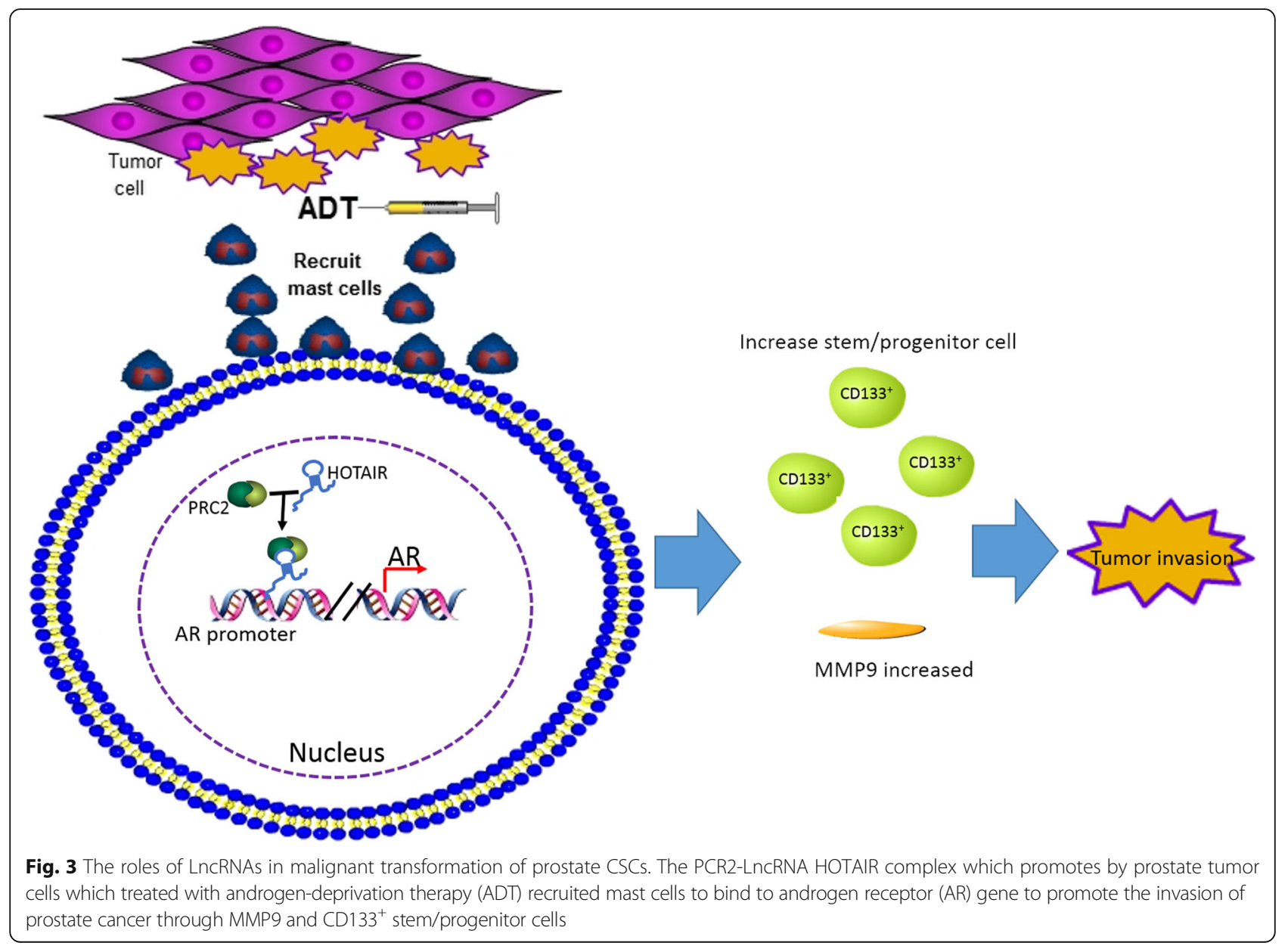


Pádua AC and other researchers reported that LncRNA HOTAIR played a key role in the occurrence of EMT in breast cancer cells. They found that treatment with the cytokine TGF- $\beta 1$ can upregulate the expression of HOTAIR and induce the occurrence of EMT. While siRNA HOTAIR can inhibit the EMT induced by TGF- $\beta 1$, it can also inhibit the cloning ability of breast cancer cells [58]. Moreover, Zhang et al. demonstrated that LncRNA HOTAIR can indirectly inhibit MIR-7, then depress SETDB1, and reverse the EMT of breast CSCs by downregulating the STAT3 pathway [59]. These studies indicate that LncRNA HOTAIR is a crucial factor in several EMTrelated signaling pathways in breast cancer. Hou et al. found that LncRNA ROR is highly expressed in breast cancer tissues and is upregulated during EMT occurrence in human mammary epithelial cells. At the same time, the migration and invasion of breast cancer cells are enhanced and exert characteristics of primary stem cells. In contrast, silencing LncRNA ROR can inhibit the growth and lung metastasis of breast cancer cells [60]. H Li reported that LncRNA 00617 was highly expressed in breast cancer tissues and can promote the invasion and EMT in breast cancer cells by activating the transcription of SOX2. They showed that LncRNA 00617 exhibited carcinogenic activity in breast cancer [61]. SOX2 is crucial to the characteristics of CSCs
[62]. Shahryari et al. showed that LncRNA SOX2OT is one of the main regulatory factors of SOX2 and found that aberrant expression of LncRNA SOX2OT and SOX2 appeared in numerous solid tumors such as breast and lung cancers [63]. This suggests that LncRNA SOX2OT may be related to the characteristics of breast CSCs (Fig. 4). Additionally, Zhou et al. reported that LncRNA-Hh can enhance the characteristics of CSCs in Twistpositive breast cancer through the Hedgehog signaling pathway [64].

In general, LncRNAs typically affect the characteristics of breast CSCs by influencing the EMT-related signaling pathways. These research achievements provide a broader space for us to study on breast CSCs. During the course of breast cancer treatment, LncRNAs could be used as new markers for early diagnosis and prognosis forecast in the future. In addition, they may also be a new therapeutic target and provide new ideas for breast cancer targeted therapy.

\section{Glioma}

Glioma is the most common tumor in the central nervous system, and it exhibits a strong invasive ability. Glioma appears to diffusely infiltrate tissue, and the main current clinical treatment methods are surgery, radiotherapy, and chemotherapy, but their effect is limited. In

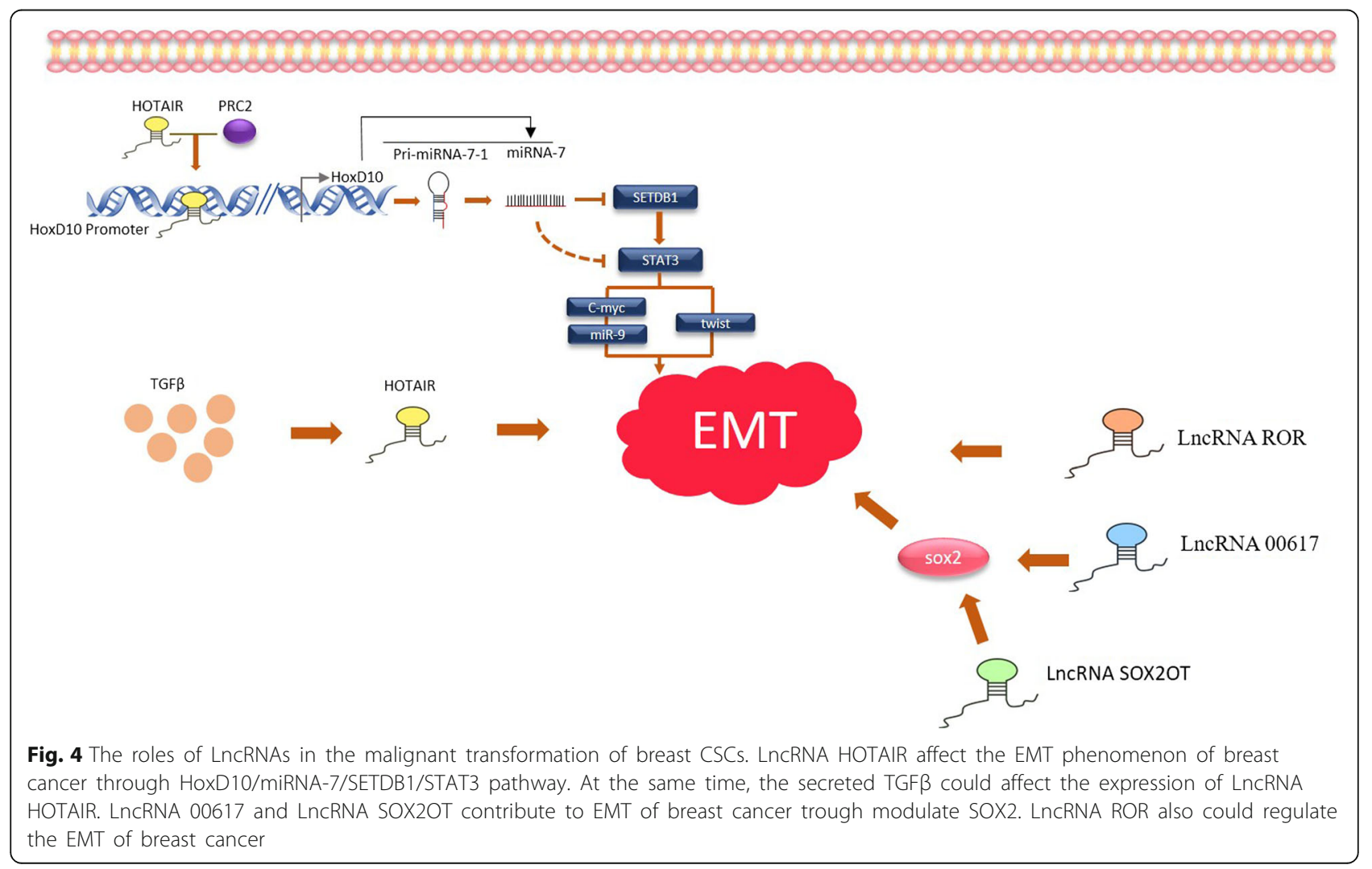


recent years, studies have indicated that the expression of various LncRNAs are aberrant in glioma. Some of the LncRNAs showed increased expression in glioma compared with normal nervous tissues. Galasso et al. found that LncRNA uc.283-plus was specific to pluripotent stem cells, and it was highly expressed in glioma cells [65]. Ellis et al. found that LncRNA CRNDE with obvious stem cell-related properties is highly expressed in many kinds of tumor cells, including the glioma cells [66]. Yao et al. reported that LncRNA XIST was highly expressed in glioma stem cells, and the results of this study showed that knockdown of the LncRNA XIST in glioma cells could lead to miR-152 upregulation, which resulted in the inhibition of CSCs [67]. Nevertheless, some of the LncRNAs showed decreased expression in glioma. Feng $\mathrm{S}$ reported that the expression level of LncRNA-ROR in glioma tissues was significantly lower than the adjacent tissues. Additionally, LncRNA-ROR silencing could significantly enhance the proliferation of glioma cells and the spheronization of glioma stem cells. At the same time, the expression of LncRNA-ROR was negatively correlated with the expression of stem cell factor KLF4, which indicated that LncRNA-ROR played an inhibitory role in the proliferation and self-renewal of glioma stem cells [68] (Fig. 5). In summary, the aberrant expression of LncRNAs plays an important role in the malignant transformation and self-renewal of glioma stem cells. As research continues, LncRNAs may become new targets for the diagnosis and treatment of glioma.

\section{Conclusions}

Research regarding the effect and mechanism of LncRNAs on CSCs' self-renewal and malignant transformation is still in the initial stages. However, the existing research indicates that the aberrant expression of LncRNAs plays a key role in the self-renewal and malignant transformation of CSCs and tumor progression. At the present stage, research regarding the effect of LncRNAs on CSCs mainly concentrates on HCC, prostate cancer, breast cancer, and glioma, and researchers have found that the mechanisms of LncRNAs in

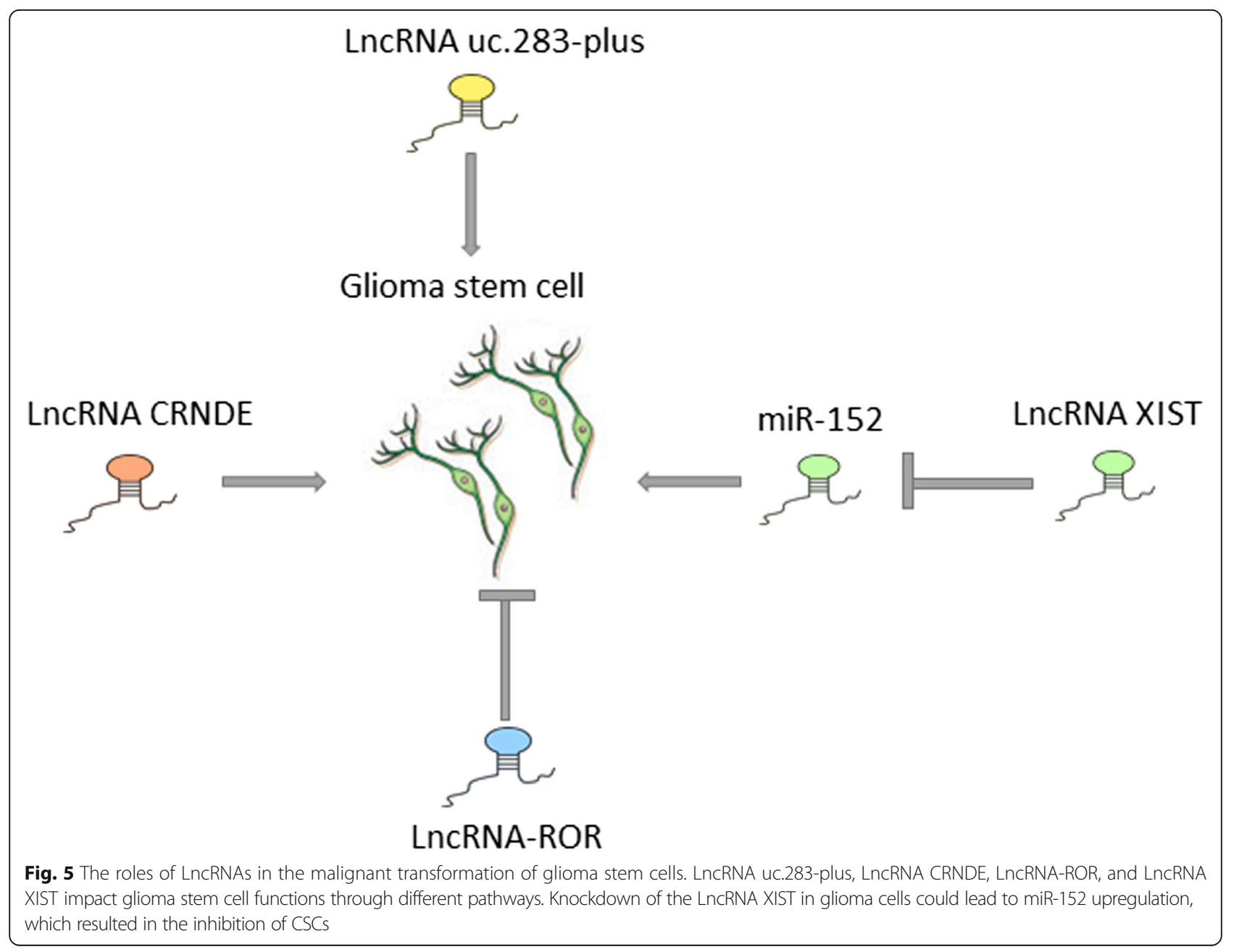


different tumors are not consistent (see Additional file 1), which include changes in histone modification, the regulation of classic stem cell-related signaling pathways such as SOX2/KLF4, the induction of EMT, and the inhibition of miRNA function. These findings indicate that LncRNAs have strong biological effects on the function and mechanisms of CSCs. Additionally, numerous studies have found that LncRNA HOTAIR, LncRNA H19, and other classical LncRNAs could regulate the self-renewal and malignant transformation of CSCs through different mechanisms in different tumors. In general, the abnormal differentiation of CSCs is crucial to metastasis and recurrence in a variety of tumors, and LncRNAs play important roles in the abnormal differentiation of CSCs. However, up to now, the researches on cancer stem cells and LncRNAs have been focused on the influence of LncRNAs aberrant expression on cancer stem cells' malignant transformation, but few studies have explored how LncRNAs change in the tumor environment. In the future, if we can clarify the relevant mechanisms, it will provide us with new ideas. We believe that the multiple functions of LncRNAs suggest that they may become novel promising targets to eradicate tumor stem cells, which may provide a new possibility for curative treatments of numerous cancers.

\section{Additional file}

Additional file 1: Summary of LncRNAs related pathways in Hepatocellular carcinoma, Prostate cancer, Breast cancer, and Glioma. (XLSX $9 \mathrm{~kb}$ )

\section{Abbreviations}

CSCs: Cancer stem cells; EMT: Epithelial mesenchymal transition; HCC: Hepatocellular carcinoma; lincRNAs: Long intergenic ncRNAs; LncRNAs: Long non-coding RNAs

\section{Acknowledgements}

Not applicable.

\section{Funding}

This work was supported by the National Natural Science Foundation of China (Nos. 81270607, 81400121, and 81541027). The funding allowed the collection and analysis of data.

\section{Availability of data and materials}

The data and material that support the conclusions of this review have been included within the article.

\section{Authors' contributions}

$\mathrm{XH}$ drafted the manuscript. RX performed the selection of literature. SP, XY, and $W Y$ collected the related references. ZT, MX, YZ, and QY prepared the figures. YW, WH, LS, and JX revised the language. QZ carried out the design of the review. All authors contributed to this manuscript. All authors read and approved the final manuscript.

\section{Competing interests}

The authors declare that they have no competing interests.
Ethics approval and consent to participate

Not applicable.

\section{Author details}

${ }^{1}$ Department of Immunology, School of Basic Medical Science, Wuhan University, Wuhan 430071, China. ${ }^{2}$ Hubei University of Technology Engineering and Technology College, Wuhan 430000, China. ${ }^{3}$ Department of Oncology, Zhongnan Hospital of Wuhan University, Wuhan 430071, China. ${ }^{4}$ Department of Hematology, Zhongnan Hospital of Wuhan University, Wuhan 430071, China

Received: 6 November 2016 Accepted: 23 February 2017

Published online: 28 February 2017

\section{References}

1. Harrow J, Frankish A, Gonzalez JM, Tapanari E, Diekhans M, Kokocinski F, Aken BL, Barrell D, Zadissa A, Searle S, Barnes I, Bignell A, Boychenko V, Hunt T, Kay M, Mukherjee G, Rajan J, Despacio-Reyes G, Saunders G, Steward C, Harte R, Lin M, Howald C, Tanzer A, Derrien T, Chrast J, Walters N, Balasubramanian S, Pei B, Tress M, Rodriguez JM, Ezkurdia I, van Baren J, Brent M, Haussler D, Kellis M, Valencia A, Reymond A, Gerstein M, Guigó R, Hubbard TJ. GENCODE: the reference human genome annotation for The ENCODE Project. Genome Res. 2012;22(9):1760-74

2. Cheng J, Kapranov P, Drenkow J, Dike S, Brubaker S, Patel S, Long J, Stern D, Tammana H, Helt G, Sementchenko V, Piccolboni A, Bekiranov S, Bailey DK, Ganesh M, Ghosh S, Bell I, Gerhard DS, Gingeras TR. Transcriptional maps of 10 human chromosomes at 5-nucleotide resolution. Science. 2005: 308(5725):1149-54.

3. Bertone P, Stolc V, Royce TE, Rozowsky JS, Urban AE, Zhu X, Rinn JL, Tongprasit W, Samanta M, Weissman S, Gerstein M, Snyder M. Global identification of human transcribed sequences with genome tiling arrays. Science. 2004; 306(5705):2242-6.

4. Kapranov P, Cheng J, Dike S, Nix DA, Duttagupta R, Willingham AT, Stadler PF, Hertel J, Hackermüller J, Hofacker IL, Bell I, Cheung E, Drenkow J, Dumais E, Patel S, Helt G, Ganesh M, Ghosh S, Piccolboni A, Sementchenko V, Tammana $H$, Gingeras TR. RNA maps reveal new RNA classes and a possible function for pervasive transcription. Science. 2007:316(5830):1484-8.

5. Kloc M, Wilk K, Vargas D, Shirato Y, Bilinski S, Etkin LD. Potential structural role of non-coding and coding RNAs in the organization of the cytoskeleton at the vegetal cortex of Xenopus oocytes. Development. 2005; 132(15):3445-57.

6. Deniz E, Erman B. Long noncoding RNA (lincRNA), a new paradigm in gene expression control. Funct Integr Genomics. 2016. doi:10.1007/s10142016-0524-x.

7. Wei S, Wang K. Long noncoding RNAs: pivotal regulators in acute myeloid leukemia. Exp Hematol Oncol. 2016:5:30

8. Iyer MK, Niknafs YS, Malik R, Singhal U, Sahu A, Hosono Y, Barrette TR, Prensner JR, Evans JR, Zhao S, Poliakov A, Cao X, Dhanasekaran SM, Wu YM, Robinson $\mathrm{DR}$, Beer DG, Feng FY, lyer HK, Chinnaiyan AM. The landscape of long noncoding RNAs in the human transcriptome. Nat Genet. 2015;47(3):199-208.

9. Sanchez-Mejias A, Tay Y. Competing endogenous RNA networks: tying the essential knots for cancer biology and therapeutics. J Hematol Oncol. 2015;8:30

10. Wei S, Zhao M, Wang X, Li Y, Wang K. PU.1 controls the expression of long noncoding RNA HOTAIRM1 during granulocytic differentiation. J Hematol Oncol. 2016;9(1):44.

11. Liu XY, Wang L, Yu B, Zhuang QY, Wang YP. Expression Signatures of Long Noncoding RNAs in Adolescent Idiopathic Scoliosis. Biomed Res Int. 2015; doi:10.1155/2015/276049

12. Zeng C, Yu X, Lai J, Yang L, Chen S, Li Y. Overexpression of the long noncoding RNA PVT1 is correlated with leukemic cell proliferation in acute promyelocytic leukemia. J Hematol Oncol. 2015;8(1):126.

13. Huang MD, Chen WM, Qi FZ, Xia R, Sun M, Xu TP, Yin L, Zhang EB, De W, Shu YQ. Long non-coding RNA ANRIL is upregulated in hepatocellular carcinoma and regulates cell apoptosis by epigenetic silencing of KLF2. J Hematol Oncol. 2015;8:50.

14. Dong S, Qu X, Li W, Zhong X, Li P, Yang S, Chen X, Shao M, Zhang L. The long non-coding RNA, GAS5, enhances gefitinib-induced cell death in innate EGFR tyrosine kinase inhibitor-resistant lung adenocarcinoma cells with wide-type EGFR via downregulation of the IGF-1R expression. J Hematol Oncol. 2015;8:43. 
15. Xu TP, Huang MD, Xia R, Liu XX, Sun M, Yin L, Chen WM, Han L, Zhang EB, Kong R, De W, Shu YQ. Decreased expression of the long non-coding RNA FENDRR is associated with poor prognosis in gastric cancer and FENDRR regulates gastric cancer cell metastasis by affecting fibronectin1 expression. J Hematol Oncol. 2014;7:63.

16. Fan $Y$, Wang YF, Su HF, Fang N, Zou C, Li WF, Fei ZH. Decreased expression of the long noncoding RNA LINC00261 indicate poor prognosis in gastric cancer and suppress gastric cancer metastasis by affecting the epithelialmesenchymal transition. J Hematol Oncol. 2016;9(1):57.

17. Wang WT, Ye H, Wei PP, Han BW, He B, Chen ZH, Chen YQ. LncRNAs H19 and HULC, activated by oxidative stress, promote cell migration and invasion in cholangiocarcinoma through a ceRNA manner. J Hematol Oncol. 2016:9(1):117.

18. Harrow J, Frankish A, Gonzalez JM, Tapanari E, Diekhans M, Kokocinski F, Aken BL, Barrell D, Zadissa A, Searle S, Barnes I, Bignell A, Boychenko V, Hunt T, Kay M, Mukherjee G, Rajan J, Despacio-Reyes G, Saunders G, Steward C, Harte R, Lin M, Howald C, Tanzer A, Derrien T, Chrast J, Walters N, Balasubramanian S, Pei B, Tress M, Rodriguez JM, Ezkurdia I, van Baren J, Brent M, Haussler D, Kellis M, Valencia A, Reymond A, Gerstein M, Guigó R, Hubbard TJ. GENCODE: the reference human genome annotation for The ENCODE Project. Genome Res. 2012;22:1760-74.

19. Guttman M, Amit I, Garber M, French C, Lin MF, Feldser D, Huarte M, Zuk O, Carey BW, Cassady JP, Cabili MN, Jaenisch R, Mikkelsen TS, Jacks T, Hacohen N, Bernstein BE, Kellis M, Regev A, Rinn JL, Lander ES. Chromatin signature reveals over a thousand highly conserved large noncoding RNAs in mammals. Nature. 2009:458(7235):223-7.

20. Tian X, Tian J, Tang X, Ma J, Wang S. Long non-coding RNAs in the regulation of myeloid cells. J Hematol Oncol. 2016;9(1):99.

21. Zhang C, Peng G. Non-coding RNAs: an emerging player in DNA damage response. Mutat Res Rev Mutat Res. 2015;763:202-11.

22. Wang KC, Chang HY. Molecular mechanisms of long noncoding RNAs. Mol Cell. 2011;43(6):904-14.

23. Eades G, Zhang YS, Li QL, Xia JX, Yao Y, Zhou Q. Long non-coding RNAs in stem cells and cancer. World J Clin Oncol. 2014;5(2):134-41.

24. Dalerba P, Cho RW, Clarke MF. Cancer stem cells: models and concepts. Annu Rev Med. 2007:58:267-84.

25. Clarke MF, Dick JE, Dirks PB, Eaves CJ, Jamieson CH, Jones DL, Visvader J, Weissman IL, Wahl GM. Cancer stem cells-perspectives on current status and future directions: AACR Workshop on cancer stem cells. Cancer Res. 2006;66(19):9339-44

26. Visvader JE, Linderman GJ. Cancer stem cells in solid tumors: accumulating evidence and unresolved questions. Nat Rev Cancer. 2008;8(10):755-68.

27. Liu C, Tang DG. MicroRNA regulation of cancer stem cells. Cancer Res. 2011; 71(18):5950-4

28. Liu K, Hao M, Ouyang Y, Zheng J, Chen D. CD133+ cancer stem cells promoted by VEGF accelerate the recurrence of hepatocellular carcinoma. Sci Rep. 2017;7:41499

29. Wang C, Yan FH, Zhang JJ, Huang H, Cui QS, Dong W, Zhang WW, Zhao Y, Chen $\mathrm{HZ}$, Zhao TJ. OV6 ${ }^{+}$cancer stem cells drive esophageal squamous cell carcinoma progression through ATG7-dependent $\beta$-catenin stabilization. Cancer Lett. 2017. doi:10.1016/j.canlet.2017.01.026.

30. Bekaii-Saab T, El-Rayes B. Identifying and targeting cancer stem cells in the treatment of gastric cancer. Cancer. 2017. doi:10.1002/cncr.30538.

31. Rasheed ZA, Kowalski J, Smith BD, Matsui W. Concise review: emerging concepts in clinical targeting of cancer stem cells. Stem Cells. 2011;29(6):883-7.

32. Herreros-Villanueva M, Zhang JS, Koenig A, Abel EV, Smyrk TC, Bamlet WR, de Narvajas AA, Gomez TS, Simeone DM, Bujanda L, Billadeau DD. SOX2 promotes dedifferentiation and imparts stem cell-like features to pancreatic cancer cells. Oncogenesis. 2013;2:e61.

33. Kumar SM, Liu S, Lu H, Zhang H, Zhang PJ, Gimotty PA, Guerra M, Guo W, $\mathrm{Xu} X$. Acquired cancer stem cell phenotypes through Oct4-mediated dedifferentiation. Oncogene. 2012;31(47):4898-911.

34. Yu F, Li J, Chen H, Fu J, Ray S, Huang S, Zheng H, Ai W. Kruppel-like factor 4 [KLF4] is required for maintenance of breast cancer stem cells and for cell migration and invasion. Oncogene. 2011;30(18):2161-72.

35. Shimono Y, Zabala M, Cho RW, Lobo N, Dalerba P, Qian D, Diehn M, Liu H, Panula SP, Chiao E, Dirbas FM, Somlo G, Pera RA, Lao K, Clarke MF. Downregulation of miRNA-200c links breast cancer stem cells with normal stem cells. Cell. 2009;138(3):592-603.
36. Yu F, Yao H, Zhu P, Zhang X, Pan Q, Gong C, Huang Y, Hu X, Su F, Lieberman J, Song $\mathrm{E}$. let-7 regulates self renewal and tumorigenicity of breast cancer cells. Cell. 2007;131(6):1109-23.

37. Li Q, Yao Y, Eades G, Liu Z, Zhang Y, Zhou Q. Downregulation of miR-140 promotes cancer stem cell formation in basal-like early stage breast cancer. Oncogene. 2014;33(20):2589-600.

38. Laursen L. A preventable cancer. Nature. 2014;516(7529):S2-3.

39. Maluccio M, Covey A. Recent progress in understanding, diagnosing, and treating hepatocellular carcinoma. CA Cancer J Clin. 2012;62(6):394-9.

40. He C, Xu J, Zhang J, Xie D, Ye H, Xiao Z, Cai M, Xu K, Zeng Y, Li H, Wang J. High expression of trimethylated histone $\mathrm{H} 3$ lysine 4 is associated with poor prognosis in hepatocellular carcinoma. Hum Pathol. 2012;43(9): 1425-35.

41. Cai MY, Hou JH, Rao HL, Luo RZ, Li M, Pei XQ, Lin MC, Guan XY, Kung HF, Zeng YX, Xie D. High expression of H3K27me3 in human hepatocellular carcinomas correlates closely with vascular invasion and predicts worse prognosis in patients. Mol Med. 2011;17(1-2):12-20.

42. Li T, Zheng Q, An J, Wu M, Li H, Gui X, Pu H, Lu D. SET1A cooperates with CUDR to promote liver cancer growth and hepatocyte-like stem cell malignant transformation epigenetically. MolTher. 2016;24(2):261-75.

43. Gui $X, L i ~ H, L i T, P u H, L u ~ D$. Long noncoding RNA CUDR regulates HULC and $\beta$-Catenin to govern human liver stem cell malignant differentiation. MolTher. 2015;23(12):1843-53.

44. Pu H, Zheng Q, Li H, Wu M, An J, Gui X, Li T, Lu D. CUDR promotes liver cancer stem cell growth through upregulating TERT and C-Myc. Oncotarget. 2015;6(38):40775-98

45. Li H, An J, Wu M, Zheng Q, Gui X, Li T, Pu H, Lu D. LncRNA HOTAIR promotes human liver cancer stem cell malignant growth through downregulation of SETD2. Oncotarget. 2015;6(29):27847-64.

46. Wang Y, He L, Ying D, Zhu P, Huang G, Luo J, Yan X, Ye B, Li C, Xia P, Zhang G, Tian Y, Chen R, Fan Z. The long noncoding RNA IncTCF7 promotes self-renewal of human liver cancer stem cells through activation of Wnt signaling. Cell Stem Cell. 2015;16(4):413-25.

47. Wang X, Sun W, Shen W, Xia M, Chen C, Xiang D, Ning B, Cui X, Li H, Li X, Ding J, Wang $\mathrm{H}$. Long non-coding RNA DILC represses self-renewal of liver cancer stem cells via inhibiting autocrine IL-6/STAT3 axis. J Hepatol. 2016;64(6):1283-94.

48. Yuan SX, Wang J, Yang F, Tao QF, Zhang J, Wang LL, Yang Y, Liu H, Wang ZG, Xu QG, Fan J, Liu L, Sun SH, Zhou WP. Long noncoding RNA DANCR increases stemness features of hepatocellular carcinoma by derepression of CTNNB1. Hepatology. 2016;63(2):499-511.

49. Conigliaro A, Costa V, Lo Dico A, Saieva L, Buccheri S, Dieli F, Manno M, Raccosta S, Mancone C, Tripodi M, De Leo G, Alessandro R. CD90+ liver cancer cells modulate endothelial cell phenotype through the release of exosomes containing H19 LncRNA. Mol Cancer. 2015;14:155.

50. Jemal A, Bray F, Center MM, Ferlay J, Ward E, Forman D. Global cancer statistics. CA Cancer J Clin. 2011;61(2):69-90.

51. Heinlein CA, Chang C. Androgen receptor in prostate cancer. Endocr Rev. 2004;25(2):276-308.

52. Niu Y, Chang TM, Yeh S, Ma WL, Wang YZ, Chang C. Differential androgen receptor signals in different cells explain why androgen-deprivation therapy of prostate cancer fails. Oncogene. 2010;29(25):3593-604.

53. Chang C, Lee SO, Yeh S, Chang TM. Androgen receptor [AR] differential roles in hormone-related tumors including prostate, bladder, kidney, lung, breast and liver. Oncogene. 2014;33(25):3225-34.

54. Li L, Dang Q, Xie H, Yang Z, He D, Liang L, Song W, Yeh S, Chang C. Infiltrating mast cells enhance prostate cancer invasion via altering LncRNAHOTAIR/PRC2-androgen receptor [AR]-MMP9 signals and increased stem/ progenitor cell population. Oncotarget. 2015;6(16):14179-90.

55. Bauderlique-Le Roy H, Vennin C, Brocqueville G, Spruyt N, Adriaenssens E, Bourette RP. Enrichment of human stem-like prostate cells with s-SHIP promoter activity uncovers a role in stemness for the long noncoding RNA H19. Stem Cells Dev. 2015;24(10):1252-62.

56. Siegel RL, Miller KD, Jemal A. Cancer statistics, 2016. CA Cancer J Clin. 2016; 66(1):7-30.

57. Ye X, Tam WL, Shibue T, Kaygusuz Y, Reinhardt F, Ng Eaton E, Weinberg RA. Distinct EMT programs control normal mammary stem cells and tumourinitiating cells. Nature. 2015;525(7568):256-60.

58. Pádua Alves C, Fonseca AS, Muys BR, de Barros E Lima Bueno R, Bürger MC, de Souza JE, Valente V, Zago MA, Silva Jr WA. Brief report: the lincRNA Hotair is required for epithelial-to-mesenchymal transition and stemness maintenance of cancer cell lines. Stem Cells. 2013;31(12):2827-32. 
59. Zhang H, Cai K, Wang J, Wang X, Cheng K, Shi F, Jiang L, Zhang Y, Dou J. MiR-7, inhibited indirectly by lincRNA HOTAIR, directly inhibits SETDB1 and reverses the EMT of breast cancer stem cells by downregulating the STAT3 pathway. Stem Cells. 2014:32(11):2858-68.

60. Hou P, Zhao Y, Li Z, Yao R, Ma M, Gao Y, Zhao L, Zhang Y, Huang B, Lu J. LincRNA-ROR induces epithelial-to-mesenchymal transition and contributes to breast cancer tumorigenesis and metastasis. Cell Death Dis. 2014;5:e1287.

61. Li H, Zhu L, Xu L, Qin K, Liu C, Yu Y, Su D, Wu K, Sheng Y. Long noncoding RNA linc00617 exhibits oncogenic activity in breast cancer. MolCarcinog. 2015. doi:10.1002/mc.22338.

62. Zhou C, Yang X, Sun Y, Yu H, Zhang Y, Jin Y. Comprehensive profiling reveals mechanisms of SOX2-mediated cell fate specification in human ESCs and NPCs. Cell Res. 2016;26(2):171-89.

63. Shahryari A, Jazi MS, Samaei NM, Mowla SJ. Long non-coding RNA SOX2OT: expression signature, splicing patterns, and emerging roles in pluripotency and tumorigenesis. Front Genet. 2015;6:196.

64. Zhou M, Hou Y, Yang G, Zhang H, Tu G, Du YE, Wen S, Xu L, Tang X, Tang $S$, Yang L, Cui X, Liu M. LncRNA-Hh strengthen cancer stem cells generation in Twist-positive breast cancer via activation of hedgehog signaling pathway. Stem Cells. 2016;34(1):55-66.

65. Galasso M, Dama P, Previati M, Sandhu S, Palatini J, Coppola V, Warner S, Sana ME, Zanella R, Abujarour R, Desponts C, Teitell MA, Garzon R, Calin G, Croce CM, Volinia S. A large scale expression study associates uc.283-plus LncRNA with pluripotent stem cells and human glioma. Genome Med. 2014;6(10):76.

66. Ellis BC, Molloy PL, Graham LD. CRNDE: a long non-coding RNA involved in cancer, neurobiology, and development. Front Genet. 2012;3:270.

67. Yao Y, Ma J, Xue Y, Wang P, Li Z, Liu J, Chen L, Xi Z, Teng H, Wang Z, Li Z, Liu Y. Knockdown of long non-coding RNA XIST exerts tumor-suppressive functions in human glioblastoma stem cells by up-regulating miR-152. Cancer Lett. 2015;359(1):75-86

68. Feng S, Yao J, Chen Y, Geng P, Zhang H, Ma X, Zhao J, Yu X. Expression and functional role of reprogramming-related long noncoding RNA (lincRNAROR) in glioma. J Mol Neurosci. 2015;56(3):623-30.

\section{Submit your next manuscript to BioMed Central and we will help you at every step:}

- We accept pre-submission inquiries

- Our selector tool helps you to find the most relevant journal

- We provide round the clock customer support

- Convenient online submission

- Thorough peer review

- Inclusion in PubMed and all major indexing services

- Maximum visibility for your research

Submit your manuscript at www.biomedcentral.com/submit

) Biomed Central 